\title{
MUDHARABAH DALAM PEMIKIRAN IBNU RUSYD
}

\author{
Sri Kurnialis ${ }^{1}$, Husni Thamrin ${ }^{2}$ \\ *1\&2 Program Studi Ekonomi Syariah Program Pascasarjana \\ Univiersitas Islam Negeri Sultan Syarif Kasim Riau \\ E-mail: 22193024702@students.uin-suska.ac.id
}

\begin{abstract}
Abstrak: Ibnu Rusyd merupakan salah satu pemikir besar dalam ekonomi Islam. Ibnu Rusyd banyak memberikan kontribusinya dalam khasanah dunia filsafat, baik filsafat yang berasal dari Yunani maupun yang berasal dari filosof-filosof Muslim. Metode analisis yang digunakan adalah Penelitian Kepustakaan (Library Research). Dan yang dijadikan sebagai data primer dalam penelitian ini yakni data yang di peroleh langsung dari sumber utama yaitu literatur-literatur yang membahas tentang mudharabah dalam pandangan Ibnu Rusyd. Hasil dari penelitian ini menunjukkan bahwa pemikiran Ibnu Rusyd banyak memberikan kontribusinya dalam khasanah dunia filsafat, baik filsafat yang berasal dari Yunani maupun yang berasal dari filosoffilosof Muslim sebelumnya. Ibnu Rusyd dalam filsafatnya sangat mengagumi filsafat Aristoteles dan banyak memberikan ulasan-ulasan atau komentar terhadap filsafat Aristoteles sehingga ia terkenal sebagai komentator Aristoteles.
\end{abstract}

Kata Kunci : Ibnu Rusyd, Mudharabah, Filsafat. 


\section{PENDAHULUAN}

Sejarah Pemikiran Ekonomi Islam yang dimulai sejak masa Rasulullah telah mengalami perbaikan. Banyak pemikir Islam yang menyumbangkan pemikirannya di bidang ekonomi dan telah mendongkrak perkembangan perekonomian yang semakin baik. Dengan landasan Al-Qur'an dan Sunnah, tokoh pemikir ekonomi Islam mampu menyaingi para pemikir ekonomi konvensional. Salah satunya adalah tokoh ekonom Islam Ibn Rusyd. Ibn Rusyd atau lebih dikenal dengan Averros ini merupakan seorang tokoh sufi yang mengedepankan tasawufnya dalam menjalani kehidupan. Hal tersebut menjadikan niatannya dalam mendekatkan diri kepada Tuhan melalui pemikiran ekonominya yang berhubungan dengan sosial. Dalam pemikirannya beliau membahas semua tentang mudharabah.

\section{TINJAUAN PUSTAKA Mudharabah}

Mudharabah adalah akad antara dua pihak, pihak pertama sebagai pemilik modal dan pihak yang lain sebagai pelaksana modal atau seseorang yang ahli dalam berdagang untuk mengoperasionalkan modal tersebut dalam usaha-usaha produktif dan keuntungan dari usaha tersebut dibagi dua sesuai dengan kesepakatan. Dan jika terjadi kerugian, maka kerugian ditanggung oleh pemberi modal, sedangkan bagi pihak pelaksana modal kerugiannya adalah kehilangan waktu, pikiran dan jerih payah yang telah dicurahkan serta manejerial (Sabiq, 2006: 212).

\section{METODE PENELITIAN}

Metode pada penelitian ini menggunakan penelitian perpustakaan
(Library Research). Dan yang dijadikan data primer dalam penelitian ini yakni mudharabah dalam pandangan ibnu rusyd dan sumber yang berkaitan dengan pembahasan ini, baik itu berupa bukubuku atau jurnal-jurnal. Penelitian ini merupakan jenis penelitian deskriptif.

\section{PEMBAHASAN \\ Biografi Ibnu Rusyd (520-595 H / 1126- $1198 \mathrm{M}$ )}

Nama asli Ibn Rusyd adalah Abu alWahid Muhammad Ibn Ahmad Ibn Muhammad Ibn Rusyd. Beliau lahir di Cordova pada tahun $520 \mathrm{H} / 1126 \mathrm{M}$. Memiliki keluarganya yang terkenal alim dalam hal ilmu Fiqh. Ayah dan kakeknya pernah menjadi kepala pengadilan di Andalausia. Latar belakang keagamaan inilah yang memberinya kesempatan untuk meraih kedudukan yang tinggi dalam studi-studi keislaman. Ibn Rusyd hidup dalam situasi politik yang sedang berkecamuk. Dia lahir pada masa pemerintahan Almurafiah yang digulingkan oleh golongan Almuhadiah di Marrakusy pada tahun $542 \mathrm{H} / 1147 \mathrm{M}$, yang menaklukkan Cordova pada tahun 543 H / 1148 M. (Syarif, 1996 : 172-203)

Gerakan Almuhadiah dimulai oleh Ibn Tumart yang menyebut dirinya sebagai Al-Mahdi. Dia berupaya meniru golongan Fatimiyah, yang muncul seabad sebelumnya dan berhasil mendirikan sebuah kekaisaran di Mesir dalam hal semangat berfilsafat mereka. Penafsiranpenafsiran rahasia mereka serta kehebatan mereka dalam bidang astronomi dan astrologi. Tiga orang pewarisnya, dari golongan Almuhadiah 'Abd Al-Mu'min, Abu Ya'qub, dan Abu Yusuf, yang diabdi oleh Ibn Rusyd, terkenal karena semangat berilmu dalam berfilsafat (Syarif, 1996 : 204). 


\section{Mudharabah dalam Pandangan Ibn Rusyd}

Ibn Rusyd menyamakan istilah mudharabah (dormant partnership) dengan qiradh atau muqaradhah. Ketiga istilah ini memiliki makna sama sebagai perkongsian modal dan usaha. Perbedaan penggunaan istilah ini sangat dimungkinkan karena faktor geografis. Kata al-qiradh dan al-muqaradhah berasal dari semenanjung tanah Arab, terutama Hijaz, sementara istilah al-mudharabah berasal dari Iraq. Perbedaan asal-usul istilah tersebut memberi kesan dan pengaruh yang cukup sensitif dalam penggunaannya oleh para ulama' dari mazhab fiqh yang tempat perkembangannya berbeda. Mazhab fiqh Maliki dan Syafi'i yang berkembang di Hijaz menggunakan istilah al-qiradh untuk akad al- mudharabah dalam penulisan mereka dan menggunakan istilah almuqaradah untuk akad al-mudharabah dalam skala yang kecil. Sementara mazhab Hanafi dan Hanbali yang berkembang di Iraq menggunakan istilah al-mudharabah untuk keduanya.

Dalam artikel ini, penulis akan menggunakan istilah al- mudharabah, meskipun sumber rujukan utama perbincangan ini menggunakan istilah alqiradh. Pertama, keduanya memberi makna yang sama. Kedua, istilah mudharabah lebih dekat dan lebih populer di Indonesia, Malaysia dan negaranegara Asean dibandingkan dengan istilah al-qiradh.

Ibn Rusyd, ketika memulai perbincangannya tentang akad almudharabah tidak mendefinisikannya secara khusus. Baik dari sudut bahasa maupun istilah fiqh sebagaimana kebiasaan para ulama' fiqh yang lain. Namun, menurut pendapat al-Imam alSarakhsi, al- mudharabah dari sudut bahasa diambil dari ayat "al-dharb fi al- ard". Istilah ini digunakan untuk menunjukkan adanya perjalanan, usaha, dan aksi oleh pelaku bisnis/usahawan (mudarib) yang berhak atas kadar tertentu dari keuntungan yang diperoleh dari hasil usaha perjalanannya dalam penyertaan modal (shahib al-mal/rabb al-mal).

Penduduk Madinah menggunakan istilah akad ini dengan al- muqaradhah atau al-qiradh. Hal ini berdasarkan pada riwayat yang menyebutkan bahwa Usman Ibn Affan sebagai khalifah Islam ketiga, sering melakukan penyertaan modal dalam bentuk akad al-muqaradhah. Istilah ini diambil dari kata dasar qardh yang berarti memotong. Karena dalam akad ini investor atau pemilik modal mengeluarkan dan memindahkan sebagian modalnya kepada usahawan atau seseorang untuk dikelola dalam investasi tertentu yang halal. Dari sinilah asal-usul istilah al-muqaradhah digunakan. Sementara, istilah al-mudharabah dikatakan berasal dari ayat al-Qur'an alKarim: "wa akharun yadribuna fi alardh..." untuk mencari rezeki dari limpahan karunia Allah SWT...."berjalan di muka bumi dengan tujuan menjalankan perniagaan dan perdagangan (Al-Sarakhsi, 1980 : 445).

Dasar akad mudharabah adalah ijab (offer) dan qabul (acceptance). Jika pemilik harta, dana, atau modal (rabb almaal) berkata kepada seseorang (usahawan atau agen) untuk mengambil modal dan menginvestasikannya dalam usaha tertentu, dan sepakat untuk berkongsi dalam kadar keuntungan tertentu seperti $1 / 2$ : $1 / 2$ atau 50:50 atau 70:30, maka akad al-mudharabah antara kedua belah pihak telah terjadi. Secara umum, mudharabah merupakan akad perkongsian antara pemilik modal (rabb al-mal) atau beberapa orang pemilik (arbab al-amwal) dengan usahawan, pekerja, atau siapapun (amil, mudharib, 
muqaridh) yang diamanahkan untuk menjalankan usaha dengan modal tersebut kemudian mengembalikan kapital kepada pemilik harta dengan kadar keuntungan yang disetujui bersama. Bagian keuntungan yang dimiliki oleh usahawan adalah dalam kadar tertentu yang disetujui bersama semasa akad. Hak ini bisa dimiliki jika usaha atau investasi itu mendatangkan keuntungan. Sebaliknya, jika mendatangkan kerugian yang bukan disebabkan oleh kelalaian dan perbuatan secara sengaja seperti masalah cuaca, gempa bumi dan keadaan ekonomi global yang menyebabkan modal habis, maka kerugian itu akan ditanggung oleh pemilik modal saja. Kerugian yang dialami oleh usahawan ialah kerugian dari sudut waktu dan tenaga yang dicurahkan dalam aktivitas usaha yang tidak mendapat keuntungan apa-apa (Tamkin, 2007: 178)

Dalam hal mengemukakan konsep dan teori mudharabah, pandangan Ibn Rusyd sama persis dengan penjelasan di atas. Dalam pandangannya, semua umat Islam sepakat atas kebolehan akad ini, bahkan menjadi bagian dari akad-akad sebelum Islam yang kemudian disahkan dalam Islam (Tamkin, 2007: 178).

\section{Legitilasi Akad Mudharabah}

Dalam kaitannya dengan legitimasi atau keabsahan akad mudharabah, Ibn Rusyd tidak mengemukakan dalil-dalil dari Al-Qur'an dan hadits Rasulullah Saw yang menjadi dasar keabsahan sebagaimana kebiasaan fuqaha' lain dalam penulisan mereka. Namun demikian, dapat dipahami dari pandangannya bahwa hadits-hadits yang dikemukakan oleh para ulama tidak perlu diungkap lagi karena sudah disetujui dan digunakan secara umum di kalangan fuqaha'.

Menurut Ibn Ishaq, sebelum masa kenabian, Nabi SAW telah menjadi manajer/pengurus/usahawan dalam akad al-mudharabah dengan Khadijah binti Khuwaylid, seorang pengusaha (trader) wanita sekaligus investor yang kaya dan dihormati yang kemudian menjadi istri Nabi. Beliau telah melakukan kongsi dagang dengan Khadijah atas dasar persetujuan memperdagangkan barang dagangan milik Khadijah ke Syam (Syiria) dan akhirnya mendapat keuntungan yang banyak.

Praktik ini membuktikan bahwa mudharabah telah diamalkan oleh orangorang Quraisy dan kaum lainnya pada zaman jahiliyah. Dan setelah kedatangan Islam, terus diamalkan sebagai alternatif bagi model atau metode perniagaan dan perkongsian antara pemodal dan pekerja atau manajer.

Dalam tahapan legitimasi dan keabsahan hukum akad selanjutnya, terdapat hadits yang menunjukkan bahwa Nabi Saw mengakui, melegalkan, dan mengesahkan praktik para sahabatnya yang terlibat dalam perniagaan berdasarkan akad mudharabah. Dalam sebuah riwayat, Nabi Saw diutus pada saat sedang maraknya penggunaan instrumen mudharabah dalam kegiatan perekonomian mereka dan tidak terdapat dalam sejarah, bahwa Nabi Saw melarang praktik atau aplikasi akad ini. Salah satu contoh, Aisyah dan Abdullah bin Umar pernah menginvestasikan harta anakanak yatim yang disimpan oleh mereka dalam akad-akad mudharabah. Demikian juga Abdullah bin Mas'ud dan al-Abbas bin Abdul Mutthalib yang senantiasa terlibat dalam akad-akad al-mudharabah. Al-Abbas, paman Rasulullah mendapat ijin dari Nabi dalam perkara ini dengan syarat-syarat yang dikenakan kepada kliennya (Al-Syarbini : 12).

Menurut para ahli fikih (fuqaha'), keabsahan akad ini mensyaratkan adanya kemampuan manajerial yang bertendensi 
pada profit atau laba (al-ribhu). Menurut al-Sarakhsi, masyarakat memerlukan akad ini karena adanya simbiosis mutualisme antara pemilik modal yang ingin berinvestasi dan pekerja atau manajer yang cakap dalam mengurus modal. Jadi, akad mudharabah ini sangat berpengaruh terhadap pertumbuhan ekonomi (growth) yang berdampak pada kesejahteraan masyarakat luas. Bagi mereka, keuntungan dari transaksi ini sangat mempengaruhi semangat kerja untuk terus melakukan upaya perniagaan dan perkongsian halal yang pada gilirannya akan mengantarkan mereka pada maqom investor atau pemilik modal.

\section{Modal Investasi Mudharabah}

Berkenaan dengan modal almudharabah, Ibn Rusyd menyatakan bahwa fuqaha' telah bersepakat membolehkan modal akad almudharabah dalam bentuk uang atau alat tukar (al-dananir dan al-darahim). Sementara, mereka berbeda pendapat jika modal yang diinvestasikan dalam bentuk barang (al-'arud/al-sila'). Para Fuqaha' dan penulis menyatakan alasan mengapa uang dijadikan modal dalam mudharabah karena memiliki nilai yang bisa dijadikan alat transaksi abadi. Berdasarkan alasan inilah para fuqaha' dalam mazhab Maliki, termasuk Ibn Rusyd dan Syafi'i tidak membolehkan penggunaan al-fulus (mata uang lokal) atau jenis mata uang yang tidak diakui sebagai modal dalam akad almudharabah.

Dalam hal modal investasi barang dan jasa, Ibn Rusyd menyatakan bahwa Jumhur Fuqaha' tidak membolehkannya. Argumen atau hujjah yang digunakan yakni karena bisa membawa kepada unsur gharar dan ketidakpastian dalam akad. Ini berlaku apabila barang yang dijadikan modal dinilai berdasarkan jumlah/harga yang berbeda oleh orang lain. Ketidakpastian nilai barang (modal) akan menimbulkan perselisihan ketika akhir transaksi (Tamkin, 2007: 178).

Selain Ibn Rusyd, dalam hal ini para fuqaha' mengemukakan alasan bahwa kemungkinan harga barang tidak stabil dalam pasar yang hanya akan menguntungkan satu pihak (instabilitas). Misalnya, jika harga barang naik, ia akan memberi keuntungan lebih kepada pekerja, hal yang sama juga berlaku jika harga barang jatuh, maka pihak pemilik modal dan pekerja akan rugi (Al-Asbahi, 1994: 834-844).

Menurut Ibn Rusyd, dari kalangan fuqaha' hanya Ibn Abi Laila yang memperbolehkan penggunaan barang sebagai modal dalam akad almudharabah dan pandangan yang sama juga telah dirujuk kepada Imam Malik sebagaimana dikutip oleh Imam alSarakhsi. Menurutnya, Imam Malik mengharuskannya karena barang bisa ditaksir dan dinilai mempunyai posisi yang sama dengan mata uang. Namun demikian, penulis tidak mendapatkan keterangan ini dalam al-muwatta' ataupun sumber lain dalam mazhab Maliki. Sebaliknya, dalam al-muwatta', Imam Malik dengan jelas menyatakan bahwa akad al-qiradh (al-mudharabah) sah jika modal investasi menggunakan mata uang (al-dananir dan al-darahim) dan tidak boleh dalam bentuk barang ('urud) ataupun (sila') (Al-Asbahi, 1089: 448 ).

Walhasil, Ibn Rusyd dan fuqaha' mazhab Maliki lainnya membenarkan penggunaan barang sebagai modal dengan syarat investor meminta pekerja menjual barang itu terlebih dahulu dan menggunakan uang tunai hasil penjualan sebagai modal.

\section{Bentuk Akad Mudharabah}

SYARIKAT : Jurnal Rumpun Ekonomi Syariah Volume 4, Nomor 2, Desember 2021 
Dalam fikih, dikenal banyak usaha dan transaksi yang berkaitan dengan aktifitas investasi sebagai upaya untuk mendapatkan laba yang halal bagi semua pihak. Dengan menggunakan modal dari shahib al-mal, seperti mudharabah, musyarakah, rahn, dan sebagainya. Dalam tulisannya, Ibnu Rusyd telah menyentuh perkara tersebut secara ringkas sebagaimana fuqaha' lain dalam mazhab Maliki dan Syafi'i. Hanya fuqaha' mazhab Hanafi telah menjelaskan dengan detail tentang peranan dan kebebasan yang bisa dimainkan oleh pekerja semasa mengoperasikan atau memutar modal shahib al-mal dan meletakkannya dalam kategori mudharabah muthlaqah (unlimited mudharabah) dan mudharabah muqayyadah (limited mudharabah) (AlSarakhsi, 1324-1331 H: 38-40).

Ibn Rusyd menegaskan bahwa setiap usaha dari pemilik modal atau investor untuk menentukan atau membatasi aktifitas perputaran modal hanya akan menyusahkan dan menyempitkan peranan pekerja atau usahawan. Oleh karena itu, dapat dipahami manakala beliau membagi jenis akad al-mudharabah ke dalam dua jenis sebagaimana pemikiran mazhab Hanafi, walau ia sendiri bermazhab Maliki. Dan sebaliknya, meletakkan akad ini dalam kategori yang umum atau unlimited mudharabah (Al-Asbahi, 1989: 452).

Fuqaha' kalangan Syafi'iyah mempunyai pemikiran yang berbeda sehubungan dengan akad mudharabah secara dua peringkat (two-tier mudharabah) seperti yang dibincangkan oleh fuqaha' Hanafi dan Maliki. Mereka berpendapat bahwa pekerja atau mitra shahibul mal tidak dibenarkan terlibat dalam akad seperti ini. Jika hal itu dilakukan, akad dianggap batal. Namun, walaupun trend umum pemikiran Syafi'iyah seperti itu, terdapat sebagian kecil ulama Syafi'iyah yang membenarkan.

Kalangan Hanafiyah membagi jenis akad mudharabah ke dalam dua jenis. Mudharabah muthlaqah (unlimited mudharabah) dan mudharabah almuqayyadah (limited mudharabah). Mudharabah muthlaqah ialah mudharabah yang pemilik modalnya memberikan kebebasan sepenuhnya kepada pekerja atau usahawan untuk melakukan investasi. Kebebasan yang dimaksud seperti:

1. Membeli dan menjual semua jenis barang maupun jasa,

2. Membeli dan menjual secara tunai,

3. Menjadikan modal (barang) sebagai deposit atau barang gadai dalam al-rahn,

4. Mengangkat pekerja/karyawan jika diperlukan,

5. Membeli atau menyewa peralatan,

6. Membawa modal dalam perjalanan,

7. Mencampurkan modal mudharabah dengan modal kepemilikan,

8. Menginvestasikan modal mudharabah dengan pihak ketiga,

9. Menginvestasikan modal mudharabah dalam akad musharakah dengan pihak ketiga. (Al-Sarakhsi, 1324-1331 H: 39040).

Dengan kata lain, perbincangan mudharabah dalam kategori ini memperbolehkan pekerja atau mitra untuk mengurus modal dalam perniagaan yang tidak terikat dengan tempat, lokasi, waktu, industri, dan pelanggan tertentu. Sesuai dengan konteks dan kesepakatan yang biasa dilakukan. Sementara, mudharabah muqayyadah (limited mudharabah) berlaku sebaliknya, ditentukan dan dibatasi di awal (AlSarakhsi: 39040). 
Pembiayaan dan Pembagian UntungRugi

Dalam hal pembiayaan (expenses) dalam "memutar" modal mudharabah seperti tempat tinggal, makan, minum dan ongkos perjalanan, Ibn Rusyd menyatakan pendapat fuqaha' terbagi ke dalam tiga pandangan, pertama, dipelopori oleh Imam Syafi'i, usahawan tidak perlu diberikan biaya kecuali atas izin dan sepengetahuan pemilik modal, kedua, usahawan boleh diberikan biaya sebagaimana pendapat Ibrahim al-Nakha'i dan al-Hasan al-Basri, ketiga, usahawan berhak terhadap biaya hidup sehari-hari seperti pakaian dan makanan jika musafir. Sebaliknya, jika bermukim di suatu kawasan, maka tidak perlu diberikan. Pandangan ini dikutip dari Imam Malik, Imam Abu Hanifah, dan mayoritas ulama.

Mayoritas fuqaha' termasuk Ibn Rusyd menyepakati bahwa keuntungan yang diperoleh dalam akad almudharabah dibagi antara pemilik modal dan pekerja berdasarkan persetujuan bersama dengan prosentase $50: 50,70$ : 30 dan sebagainya. Sebagaimana praktik yang ditunjukkan oleh Rasulullah SAW dalam bertransaksi mudharabah dengan Khadijah binti Khuwaylid sebelum masa kenabian.

Persetujuan bersama ini dibuat oleh kedua pihak sebelum akad atau kontrak dilaksanakan dan ditandatangani di atas materai. Jika kemudian ada pihak yang menetapkan jumlah tertentu dari keuntungan yang diperoleh untuk dirinya tanpa berdasarkan kepada jumlah yang disepakati atau kurang, maka akad mudharabah dianggap batal. Alasannya, karena kontrak tersebut tidak adil dan merugikan pihak lain. Pekerja atau mitra hanya boleh mengambil bagian keuntungannya, setelah menyerahkan semua modal yang investasi kepada pemilik modal.
Seandainya investasi itu mengalami kerugian yang bukan disebabkan oleh kecurangan pekerja, maka ia akan ditanggung pemilik modal. Pandangan ini dikemukakan oleh mayoritas fuqaha'. Prinsip umum yang diaplikasikan dalam akad mudharabah ialah kedua pihak menanggung resiko. Oleh karena itu, kadang-kadang akad mudharabah disebut juga sebagai "partnership in profit" atau "profit-sharing" atau "profit and loss-sharing".

Dalam kitab-kitab fikih, sangat sedikit disinggung tentang penyelesaian akad smudharabah. Secara umum, perkongsian mudharabah diselesaikan sesegera mungkin oleh kedua pihak yang terlibat dalam kontrak yaitu setelah tujuan (keuntungan) tercapai atau diketahui dengan pasti jumlah kerugian (jika ada). Dalam hal kerugian pun, pekerja diminta untuk memulangkan modal yang tersisa. Para fuqaha' menyatakan bahwa sebab-sebab yang menyebabkan akad mudharabah boleh segera diselesaikan jika ada pengunduran, pembatalan, atau penarikan diri oleh satu pihak, juga adanya kematian dan insiden darurat seperti gila, stress dan sebagainya. Dalam kitab Bidayah alMujtahid, Ibn Rusyd hanya menyentuh secara singkat bahwa akad mudharabah akan tamat dengan sendirinya dengan kematian satu pihak sebagaimana pandangan jumhur fuqaha'. Namun begitu, Imam Malik memperbolehkan akad itu diwariskan kepada ahli waris hingga selesai.

\section{SIMPULAN}

Dari paparan singkat di atas dapat disimpulkan bahwa Ibn Rusyd dalam kapasitasnya sebagai seorang ulama ensiklopedis yang disegani, telah memberikan sumbangan pemikiran yang amat besar terhadap bidang ekonomi 
Islam. Utamanya dalam bab yang sedang diperbincangkan, yaitu akad mudharabah secara khusus, dan bidang kajian fikih smuamalah secara umum. Sebagaimana tertuang dalam kitabnya Bidayah alMujtahid wa Nihayah al-Muqtasid, walaupun dalam diskursus yang cukup ringkas dalam perspektif perbandingan mazhab fikih. Sebagaimana hal tersebut dilakukan oleh ulama dari kalangan Hanafi, seperti Al-Sarakhsi dalam kitabnya al-Mabsut.

Sumbangan pemikiran dan kontribusi Ibn Rusyd ini sangat penting bagi perkembangan dan pertumbuhan sektor keuangan dan ekonomi Islam atau sektor muamalah secara umum, utamanya jika dikaitkan dengan implementasinya dalam negara "Islam" yang sedang menggeliat seperti Indonesia, Malaysia, Pakistan, dan Iran. Dan yang lebih penting lagi, sistem ini akan menjadi rujukan bagi negara-negara non Muslim lainnya, dan akan berlaku secara global.

\section{DAFTAR RUJUKAN}

Al-Asbahi, Malik b. Anas (1989).

Al-Asbahi, Malik b. Anas. (1089), AlMuwatta', versi Yahya b, Yahya Kanthir al-Laythi, Beirut: Dar- AlFikr.

Al-Asbahi. (1994). Vol. 3 hlm. 630.

Al-Sarakhsi. (1324-1331 H). Majallah alAhkam al-Adliyyah. Vol. 22.

Al-Syarbini. Kitab al-Asl, Kitab alMadharabah. MS. Dar al-Kutub alMisriyyah. Fiqh Hanafi 491. Vol. 42.

Husein, Raef T.A. (1986). The Early Arabian Trade and marketing" dalam The Islamic Quarterly. Vol.30.

Sabiq, Sayyid. (2006). Fiqh al-Sunnah Juz II. Beirut: Dar al-Kitab al-Arabiyah.

Syarif. (1996). Para Filosofi Muslim. Bandung: Mizan.
Borhan, J. T., \& Sa'ari, C. Z. (2007). Sumbangan Pemikiran Ibn Rushd (M. 595/1198) dalam Muamalah: Analisis Terhadap Akad AlMudarabah dalam Bidayah alMujtahid wa Nihayah al-Muqtasid. Jurnal Usuluddin, 26, 133-147. 